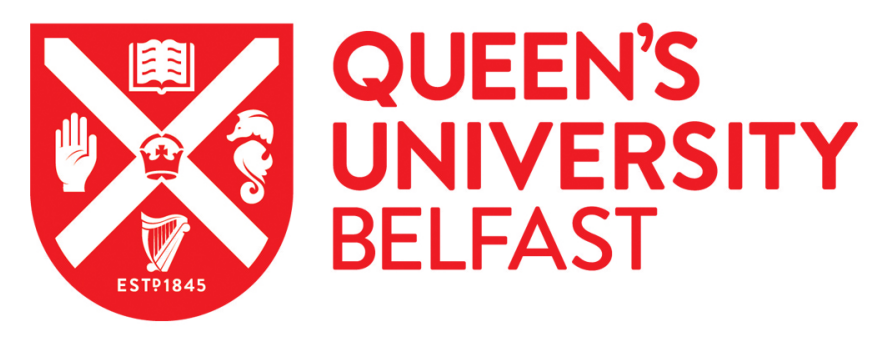

\title{
Geochemical background and dispersion pattern of the world's largest REE deposit of Bayan Obo, China
}

Zhou, J., Wang, X., Nie, L., McKinley, J., Lui, H., Zhang, B., \& Han, Z. (2020). Geochemical background and dispersion pattern of the world's largest REE deposit of Bayan Obo, China. Journal of Geochemical Exploration, 215, [106545]. https://doi.org/10.1016/j.gexplo.2020.106545

Published in:

Journal of Geochemical Exploration

Document Version:

Peer reviewed version

Queen's University Belfast - Research Portal:

Link to publication record in Queen's University Belfast Research Portal

\section{Publisher rights}

Copyright 2020 Elsevier.

This manuscript is distributed under a Creative Commons Attribution-NonCommercial-NoDerivs License

(https://creativecommons.org/licenses/by-nc-nd/4.0/), which permits distribution and reproduction for non-commercial purposes, provided the author and source are cited

\section{General rights}

Copyright for the publications made accessible via the Queen's University Belfast Research Portal is retained by the author(s) and / or other copyright owners and it is a condition of accessing these publications that users recognise and abide by the legal requirements associated with these rights.

Take down policy

The Research Portal is Queen's institutional repository that provides access to Queen's research output. Every effort has been made to ensure that content in the Research Portal does not infringe any person's rights, or applicable UK laws. If you discover content in the Research Portal that you believe breaches copyright or violates any law, please contact openaccess@qub.ac.uk. 


\title{
Geochemical background and geochemical characters of REE during hypergene processes in Bayan Obo, China
}

\author{
Xueqiu Wang ${ }^{\mathrm{a}, c^{*}}$, Jian Zhou ${ }^{\mathrm{a}, \mathrm{b}, \mathrm{c}}$, Lanshi Nie ${ }^{\mathrm{a}, \mathrm{c}}$, Jennifer McKinley ${ }^{\mathrm{d}}$, Hanliang Liu ${ }^{\mathrm{a}, \mathrm{c}}$, Bimin \\ Zhang ${ }^{\mathrm{a}, \mathrm{c}}$, Zhixuan Han ${ }^{\mathrm{a}, \mathrm{c}}$ \\ ${ }^{a}$ UNESCO International Centre on Global-scale Geochemistry, Langfang, Hebei 065000, China \\ ${ }^{\mathrm{b}}$ School of Earth Sciences and Resources, China University of Geosciences (Beijing), Beijing 100083, \\ China \\ ${ }^{\mathrm{c}}$ Key Laboratory of Geochemical Exploration, Institute of Geophysical and Geochemical Exploration, \\ Langfang, Hebei 065000, China \\ ${ }^{d}$ School of Natural and Built Environment, Queen's University Belfast, UK
}

\begin{abstract}
The Bayan Obo deposit is the largest light rare earth element (LREE) deposit in the world, with its REE reserve accounting for roughly $45 \%$ of the world's total. In this paper, we identify the geochemical background of rare earth elements (REEs) in the west orebody of Bayan Obo deposit and investigate the REE distribution in a weathering profile, the dispersion pattern along a stream and the fractionation between parent rocks and soils to reveal the geochemical behavior of REE during hypergene processes in semi-arid grasslands. The results show that the REE contents in the slates of the Bilute Formation, Jianshan Formation, and Dulahala Formation, which are the country rocks of the Bayan Obo deposit, are far higher than those in the continental crust of the North China Craton, and far higher than those in ordinary slate. During subsequent stages of magmatism, these rocks might have provided sufficient REE sources to form this giant world-class REE deposit. The REE content in soil is primarily determined by parent rock, and basically, no fractionation will occur between heavy and light REEs after the parent rock weathering in semi-arid grasslands region. Across the soil profile, REEs are typically enriched in the surface and deep layers, whereas the REE content is usually lower due to the existence of caliche in the middle horizon. Along streams, REEs migrate primarily by mechanical means, migrating with fine-grained particles over long distances (7 km or longer). In contrast, coarse-grained particles mainly remained in situ. Affected by aeolian sand, the REE content is relatively low in $40-80$ mesh fraction.
\end{abstract}

\section{Introduction}

The International Union of Pure and Applied Chemistry defines REEs as 15 lanthanides on the periodic table with atomic numbers from 57 to 71 , plus yttrium and scandium, which are included as REEs since they are chemically and physically similar to and are closely associated with lanthanides. As REEs are increasingly used in hi-tech applications such as magnets, catalysts, metal alloys, electronics, glass, ceramics, and new materials, they are defined as critical mineral resources by the IUGS Resourcing Future Generations initiative (Alonso and Sherman et al., 2012; Dutta and Kim et al., 2016; Zhou and Li et al., 2017).

The Bayan Obo Fe-REE-Nb deposit is located at the northern margin of the North China Craton (NCC), approximately $150 \mathrm{~km}$ north of Baotou City, Inner Mongolia, China. It is the largest REE deposit in the world, the second largest niobium $(\mathrm{Nb})$ deposit in the world, and also a major iron (Fe) deposit in China. Within this deposit, at least $90 \%$ of the REEs exist as separate minerals, predominantly as LREE minerals such as monazite and bastnaesite, which are mainly mined by opencast operations (Wang and $\mathrm{Xu}$ et al., 2019). Thus far, research on Bayan Obo has mainly focused on the genesis and exploitation of this 
deposit (Bai, 2012; Sun and Zhu et al., 2014; Smith and Campbell et al., 2015; Yang and Lai et al., 2015; Fan, 2016; Yang and Lai et al., 2017; Liu and Ling et al., 2018; Zhou and Hu et al., 2018). Attention has also been paid to the soil and environmental aspects of REEs (Duan, 2012; Guo and Fu et al., 2013; Pan and Li, 2015; Lin and Zhang, 2017; Wang and Jiao et al., 2018). As yet, however, little research has been undertaken with respect to the geochemical background and hypergene geochemical processes of REE in Bayan Obo.

In 1978, "Regional Geochemistry-National Reconnaissance Program" (RGNR) was launched in China, which has, up to now, lasted for more than 40 years, covered an area of 7 million $\mathrm{km}^{2}$ at a scale of 1:200 000(Xie, 1992; Wang, 2013; Wang, 2013), however only two REEs (La and Y) were analyzed, thus providing very limited information about the REE distribution and background in Bayan Obo area. With the exploitation and application of REEs, more REEs are brought into the soil, leading to a wide array of eco-environmental concerns in this area (Wang and Xu et al., 2019). Therefore, it is urgent to identify the geochemical background and migration mechanisms of REEs in Bayan Obo area.

\section{Geological background and landscapes of the study area}

\subsection{Geological background}

The Bayan Obo deposit, as one of the world's rare polymetallic deposit, is extended 18 $\mathrm{km}$ from east to west with approximately $3 \mathrm{~km}$ width. The deposit lies on the northern margin of the North China Craton, bordering the Central Asian Orogenic Belt on the north. It is hosted by Paleo- to Mesoproterozoic rocks of the Bayan Obo Group, which uncomfortably overlies the basement complex(Zhu and Sun et al., 2015; Hong-Rui, 2016; Liu and Ling et al., 2018) (Fig.1). Based on iron grade (TFe $>20 \%$ ), the Bayan Obo deposit can be separated into three major ore bodies: Main, East, and West orebodies (Fig.1).

Regional exposures in Bayan Obo include the Archean-Paleoproterozoic basement complex, the Paleo- to Mesoproterozoic Bayan Obo group, and Paleozoic and Mesozoic sediments (Fan, 2016). The Bayan Obo group comprises Bilute, Halahuogete, Jianshan, and Dulahala formations, which consist of sandstones with low grade metamorphism, siltstones, slates, limestones, and dolomites. The Silurian comprises the Upper Bateaobao group's Haliqi formation and Aibugaihe formation, which consist of quartz sandstones, slates, tuffs, andesites, and marbles that mainly distributed in the northeast of the deposit. Upper Jurassic sandstones and shales are mainly found in the northeast.

Regionally, the area has experienced four stages of magmatism: Wutaian-Luliangian, Caledonian, Variscan, and Yanshanian (Yang and Lai et al., 2015). Middle Variscan biotite granite, granodiorite, Late Variscan biotite granite, and gneissose biotite granite are widely distributed in the study area. 


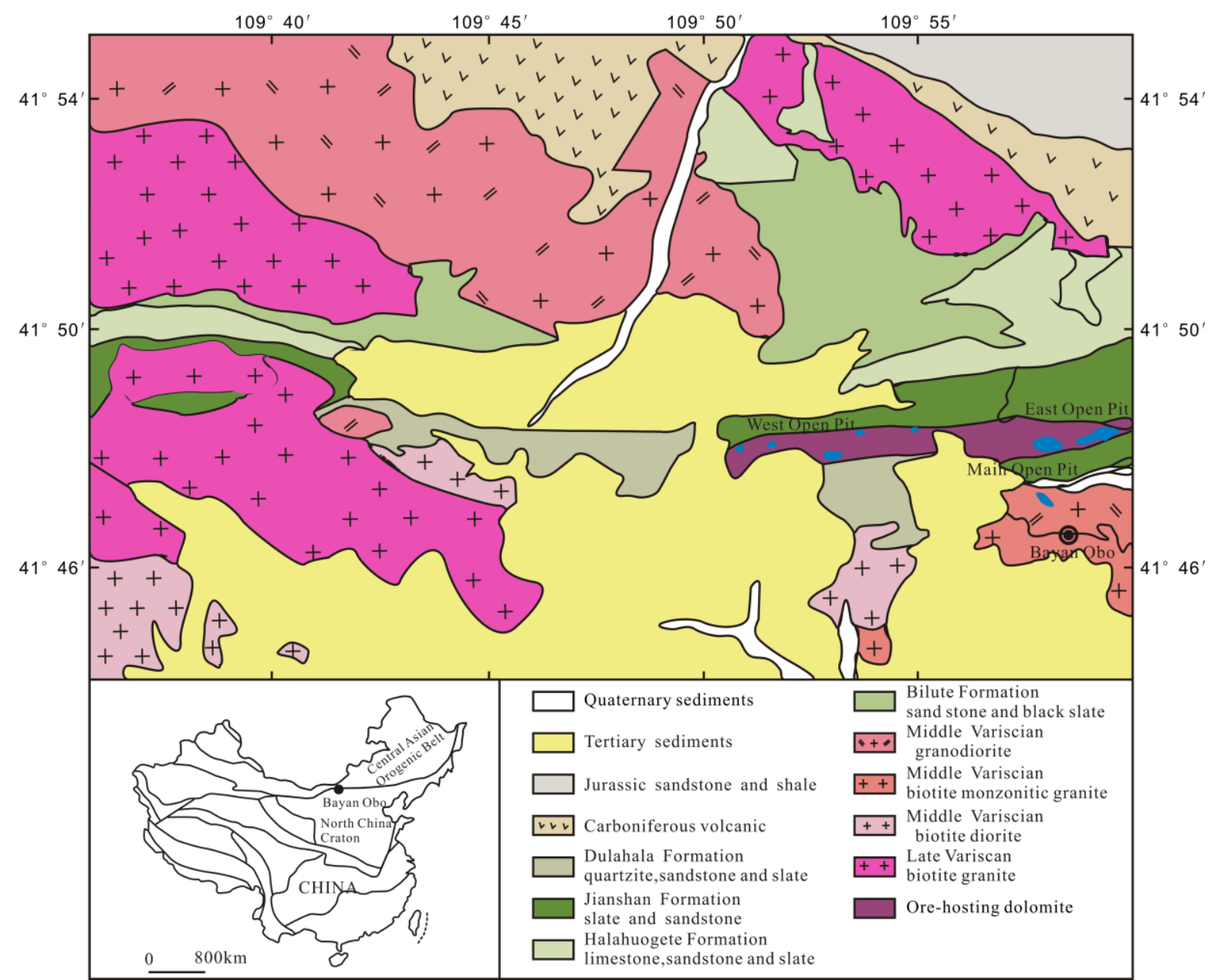

Fig. 1 Geological setting of Bayan Obo district (Modified from 1:200 000 geological map and Hong-Rui, 2016; Liu and Liu et al., 2018)

\subsection{Geochemical landscapes}

The study area lies in the south of the Mongolian Plateau in an inland arid climate zone. Affected by strong cold air from Siberia, Lake Baikal, and Ondorhaan, the climate is cold, dry, and windy, with distinct temperature differences. The prevailing annual wind direction is northwest (Gao and Ding et al., 2017). The altitude is normally 1000-1100 m above sea level, with relative height differences of 50-200 m (Kong and Zhang et al., 2004). Soil and stream sediments are commonly blended with aeolian sand. Intense evapo-transpiration has resulted in elevated surface water and groundwater mineralization. Huge accumulations of calcium carbonates, calcium sulfates, and soluble salts in the soil have produced an alkaline environment and alkaline barriers (Ren and Zhao et al., 1984).

\section{Sampling and analytical methods}

Over the long mining history of the main orebody of Bayan Obo, deposition of materials has caused REE contamination in the surrounding area. Considering that the prevailing wind direction in this area is northwest, to minimize the potential impact of REE contamination on the results of our study, we selected the northwestward streams to the west orebody for investigation. To verify whether this district has been contaminated by dust fall, we collected three soil samples from sites about $500 \mathrm{~m}, 700 \mathrm{~m}$, and $900 \mathrm{~m}$ from the west orebody (Fig.2). The REE contents are $189 \mu \mathrm{g} / \mathrm{g}, 239 \mu \mathrm{g} / \mathrm{g}$, and $240 \mu \mathrm{g} / \mathrm{g}$, respectively, which approximate the background value of $225 \mu \mathrm{g} / \mathrm{g}$ for the study area (200 $\mathrm{km}^{2}$ geochemical background of the 1: 200000 geochemical mapping for Bayan Obo). 
Hence, it can be assumed that the study area wasn't contaminated at the time the samples were collected.

To study the horizontal dispersion pattern of REEs along the stream, research work was carried out along the northwestward streams from the west orebody of Bayan Obo deposit (Fig.2). Samples were collected every 500-800 m starting from the west orebody. Each sample was sieved into five fractions: 4-20 mesh, 20-40 mesh, 40-80 mesh, 80-120 mesh, and $<120$ mesh.

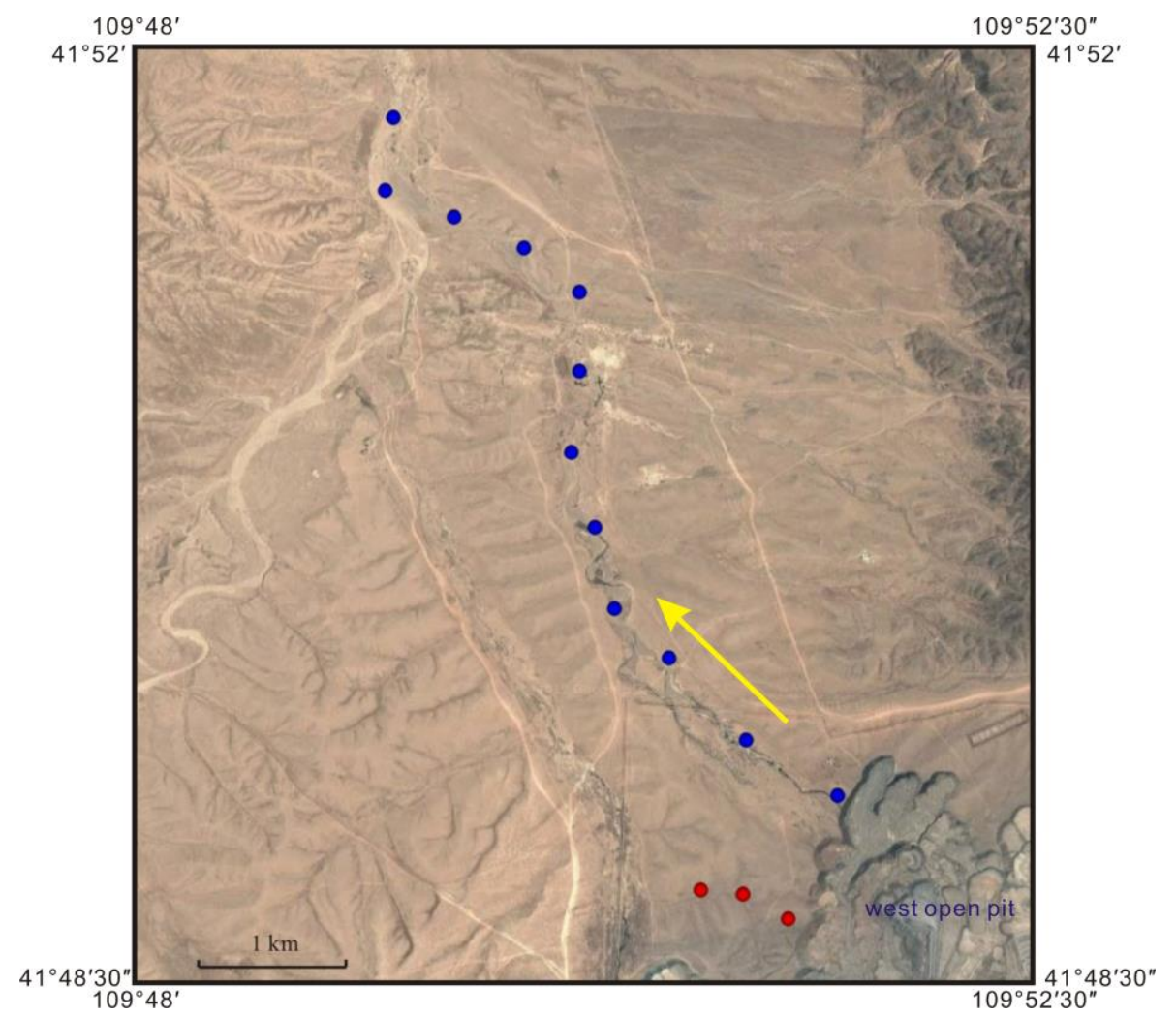

Fig. 2 Schematic map of the sample locations along the stream (modified from Google Maps, the blue spots denote sampling locations along the stream and the red spots denote those used to verify whether this area has been contaminated)

Fig. 3 shows the actual profile that was sampled for this study, about $1 \mathrm{~km}$ from the west orebody (E109'50'05.23"; N4148'48.93). Five samples were collected along the weathering profile at about $10 \mathrm{~cm}$ intervals until the bedrock. Each of the samples was sieved into five fractions. 


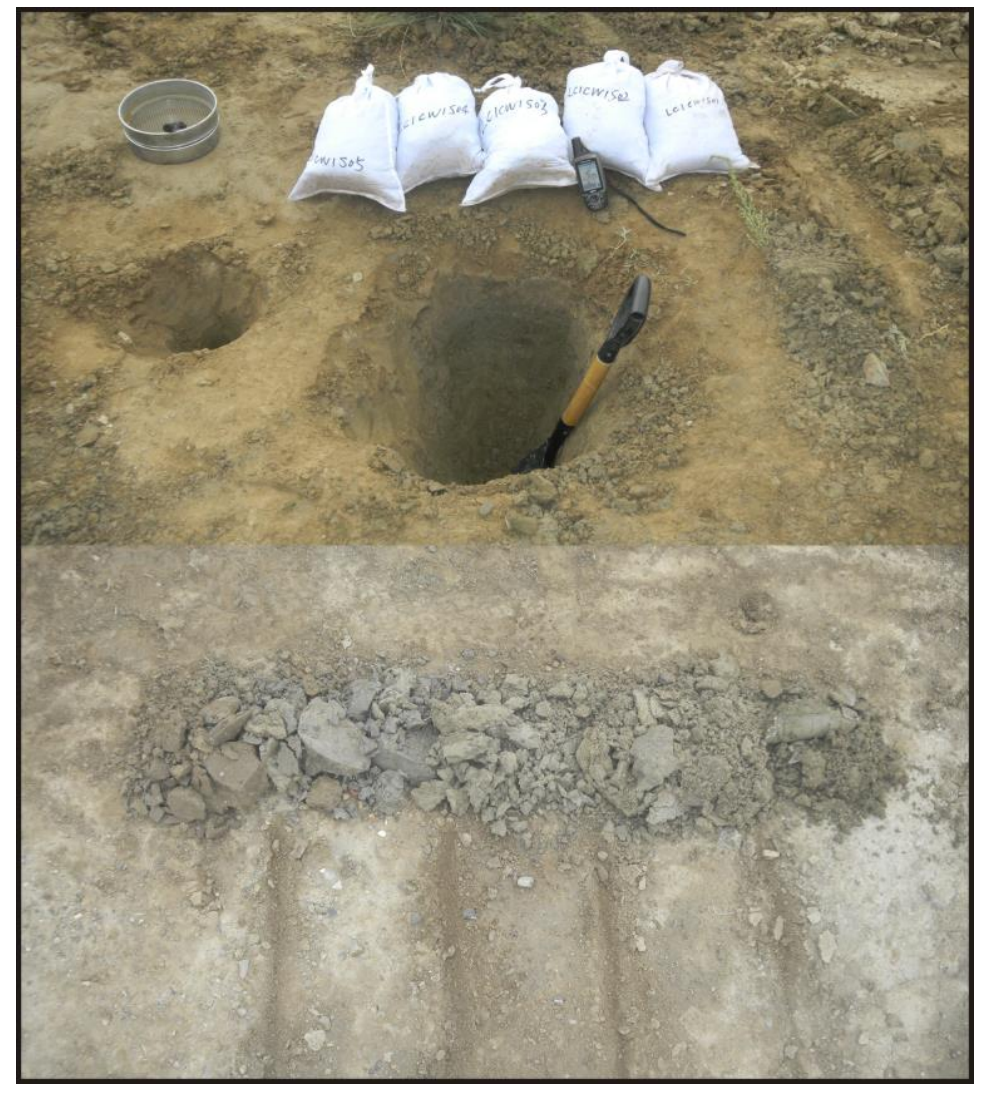

Fig. 3 Soil profile near west orebody

Magmatic, sedimentary and metamorphic rocks from different periods and soils formed by in-situ weathering of rocks in the study area are systematically collected to reveal the geochemical background and the REEs fractionation between parent rocks and soils.

\section{Results and Discussion}

\subsection{Mineralogical composition}

The samples collected along streams were sieved into five fractions: 4-20 mesh, 20-40 mesh, 40-80 mesh, 80-120 mesh, and $<120$ mesh. We performed X-ray powder diffraction (XRPD) analysis to determine the mineralogical compositions, the results of which are presented in Table 1.

Table 1 Mineralogical composition by X-ray powder diffraction

\begin{tabular}{|c|c|c|c|c|c|c|c|c|c|c|c|c|c|}
\hline & & & & & & Mine & al Cont & tent $(\%)$ & & & & & \\
\hline Fraction & $\begin{array}{c}\text { Quart } \\
\text { z }\end{array}$ & $\begin{array}{c}\text { K-feldsp } \\
\text { ar }\end{array}$ & $\begin{array}{l}\text { Plagiocla } \\
\text { se }\end{array}$ & $\begin{array}{c}\text { Total } \\
\text { quartz } \\
\& \\
\text { feldspa } \\
r\end{array}$ & Illite & $\begin{array}{c}\text { Smectit } \\
\mathrm{e}\end{array}$ & $\begin{array}{c}\text { Kaolinit } \\
\mathrm{e}\end{array}$ & $\begin{array}{c}\text { t Chlorit } \\
\mathrm{e}\end{array}$ & $\begin{array}{l}\text { Total } \\
\text { clay }\end{array}$ & $\begin{array}{c}\text { Calcit } \\
\mathrm{e}\end{array}$ & $\begin{array}{c}\text { Dolomit } \\
\mathrm{e}\end{array}$ & $\begin{array}{c}\text { Carbonat } \\
\text { es }\end{array}$ & $\begin{array}{c}\text { Hornblen } \\
\text { de }\end{array}$ \\
\hline $\begin{array}{l}4-20 \\
\text { mesh }\end{array}$ & 36.4 & 18.8 & 21.3 & 76.4 & 9.2 & 1.5 & 1.2 & 1.0 & 12.0 & 9.3 & & 9.3 & 1.5 \\
\hline $\begin{array}{l}20-40 \\
\text { mesh }\end{array}$ & 44.9 & 19.2 & 16.5 & 80.6 & 5.0 & 2.2 & 1.0 & & 7.8 & 8.1 & 0.02 & 8.1 & 1.0 \\
\hline $\begin{array}{l}40-80 \\
\text { mesh }\end{array}$ & 38.7 & 22.9 & 22.5 & 84.1 & 3.8 & 1.8 & 1.4 & 3.0 & 7.3 & 5.1 & 0.02 & 5.1 & 1.0 \\
\hline
\end{tabular}




\begin{tabular}{cccccccccccccc}
\hline $\begin{array}{c}80-120 \\
\text { mesh }\end{array}$ & 36.3 & 20.4 & 24.2 & 80.9 & 4.0 & 3.2 & 1.3 & & 8.5 & 6.8 & & 6.8 & 1.8 \\
$\begin{array}{c}<120 \\
\text { mesh }\end{array}$ & 34.7 & 15.3 & 25.4 & 75.3 & 5.3 & 5.2 & 2.8 & 1.0 & 13.8 & 6.3 & & 6.3 & 1.8 \\
$\begin{array}{c}\text { Bulk } \\
\text { size }\end{array}$ & 37.5 & 20.8 & 20.4 & 78.8 & 7.6 & 2.2 & 1.2 & 1.0 & 11.1 & 8.5 & 0.01 & 8.5 & 1.8 \\
\hline
\end{tabular}

As can be seen from Table 1, the XRPD analysis identified the following mineral phases: quartz and feldspar, which represent $75.3-84.1 \%$ of the total; clay minerals such as kaolinite, illite, smectite, and chlorite, which represent $7.3-13.8 \%$; carbonate minerals, which represent 5.1-9.3\%. Overall, quartz and feldspar minerals account for the largest proportion, followed by clay minerals and carbonate minerals.

From Fig.4, the total amount of quartz and feldspar shows an inverted "V" distribution pattern, with the highest content for 40-80 mesh and lowest contents for the coarse fraction (4-20 mesh) and the fine fraction $(<120$ mesh). The total amount of clay is just the opposite, showing a "U" distribution pattern, with the highest contents for coarse fraction and fine fraction. The total amount of carbonates is the lowest for the 40-80 mesh fraction and relatively high for the coarse fraction and fine fraction.

The relatively high quartz and feldspar content in the 40-80 mesh fraction of the study area is mainly affected by aeolian sand, of which $40-80$ mesh is the main grain size. Microscopic observations of the rounded or semi-rounded shapes of quartz and feldspar in 40-80 mesh fraction also suggest there is a large amount of aeolian sand mixed. When aeolian sand is blended into the sampled media, the concentrations of REEs will obviously decrease due to dilution.
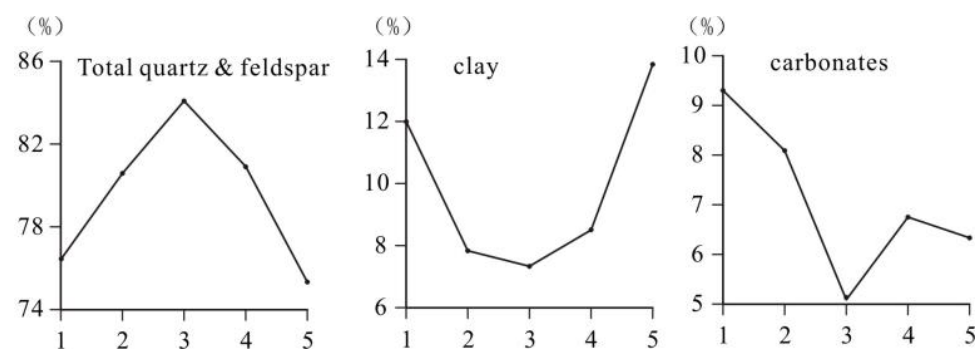

Fig. 4 Mineralogical composition of different fractions (1, 4-20 mesh; 2, 20-40 mesh; 3, 40-80 mesh; 4, 80-120 mesh; 5, <120 mesh)

\subsection{Rock geochemical background of REEs in Bayan Obo}

Rock samples from different periods were collected in the study area. Fig. 5 shows the stratigraphic column and horizons of the analyzed samples in this study.

As can be directly observed from Fig. 5, the total REE contents of Bilute Formation slate $(361 \mu \mathrm{g} / \mathrm{g})$, Jianshan Formation slate $(320 \mu \mathrm{g} / \mathrm{g})$, and Dulahala Formation slate (305 $\mu \mathrm{g} / \mathrm{g}$ ) of Bayan Obo group are the highest. This total REE content is far higher than that in either the continental crust $(106 \mu \mathrm{g} / \mathrm{g}$ ) (Gao and Rudnick et al., 2004) or the continental crust of the North China Craton $(133 \mu \mathrm{g} / \mathrm{g}$ ) (Yan and Chi, 2005). It is also far higher than the total REE of $211 \mu \mathrm{g} / \mathrm{g}$ for ordinary slate (Yan and Chi, 2005). The REE content in slate and acidic rocks is higher than that in quartzite, sandstone, and limestone. The slates of the Jianshan Formation and Hulahala Formation, which represent the country rock of the Bayan Obo REE deposit, might have provided sufficient REE sources for forming this giant world-class REE deposit. 
The REE content in Middle Caledonian fine-grained dolomite is relatively high compared to other magmatic rocks in the study area. The total REE contents of magmatic rocks from any other period are lower than the average value of granite in China (Yan and Chi, 2005). 
$\operatorname{REE}(\mu \mathrm{g} / \mathrm{g})$

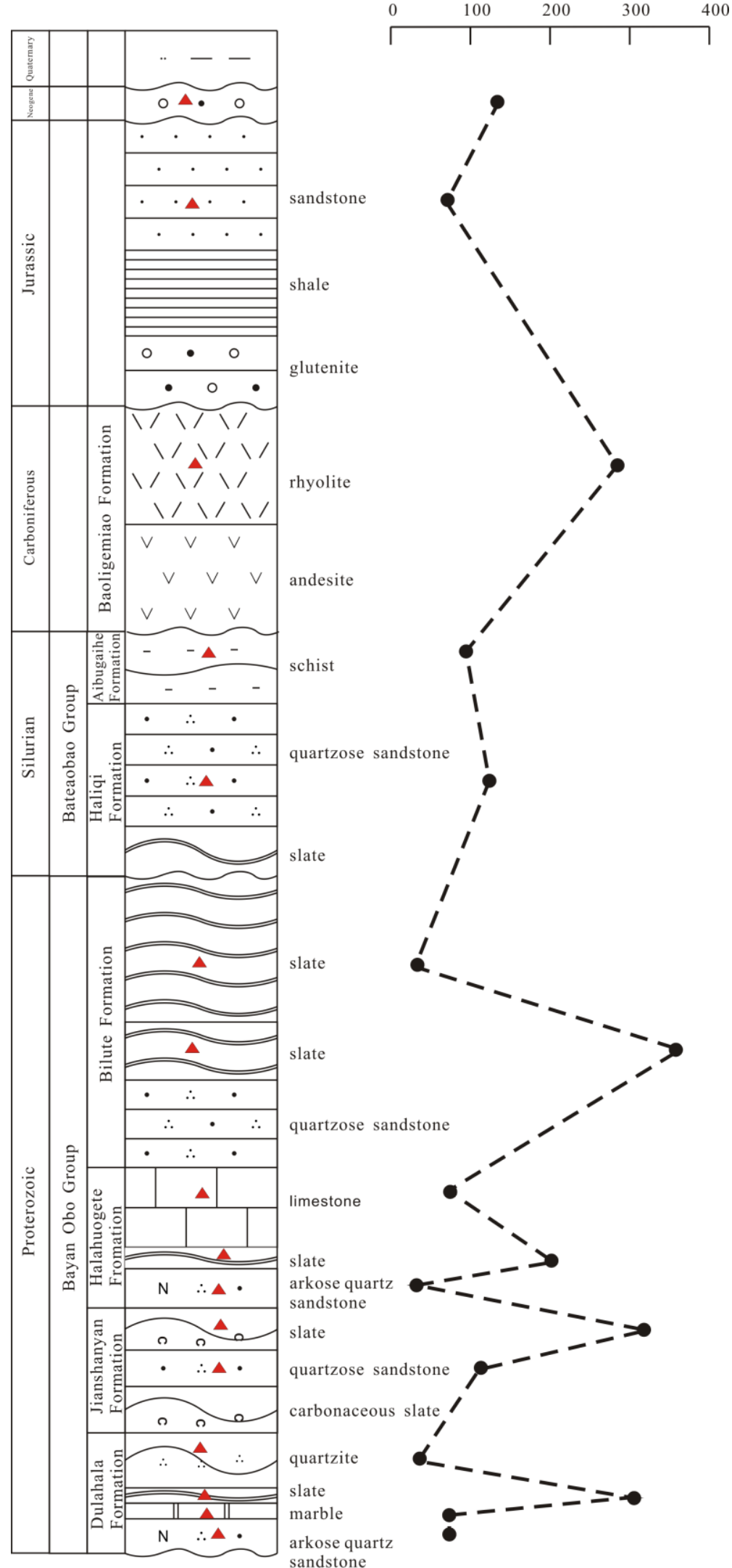


Fig. 5 Stratigraphic column of Bayan Obo and REE contents in the formations (red triangles denote the sampling horizon; key references used for constructing this column include a 1:200 000 geological map and Zhong and Zhai et al., 2015; Zhou and Hu et al., 2018)

\subsection{REE in parent rocks and in situ soils}

Samples from the main rock exposures in the study area contained biotite granite, monzogranite, rhyolite, feldspar quartz sandstone, biotite-plagioclase-hornblende schist, dolomite, and slate. Soil samples formed by in-situ weathering of rocks were also collected.

From Fig. 6, we can see that secondary enrichment of REEs has occurred in soils formed by the weathering of sandstone, dolomite, and biotite-plagioclase-hornblende schist, and there is slight depletion of the REEs in soils formed by the weathering of the slate, while the REE contents in soils formed by the weathering of biotite granite, monzogranite, and rhyolite are basically unchanged.

Overall, the REE content in soils is primarily determined by the parent rocks. The chondrite normalized REE patterns of soils are similar to that of the parent rocks, indicating that in the semi-arid grasslands region, basically, no fractionation will occur between heavy and light REEs after the parent weathering, suggesting the REE distribution pattern has good inheritance.

During chemical weathering, cerium $(\mathrm{Ce})$ tends to behave differently from other REE. Cerium in oxidizing environment occurs as $\mathrm{Ce}^{4+}$, highly insoluble as $\mathrm{CeO}_{2}$ whereas the other REEs maintain their $3^{+}$ionic states and are leached by circulating water(Mihajlovic and Rinklebe, 2018). The absence of Ce anomaly in the soils of the study area indicates that the area is dominated by physical weathering process, and chemical weathering process is relatively weak.

Hence, it is possible to determine the sources by the REE distribution pattern in sediments. 


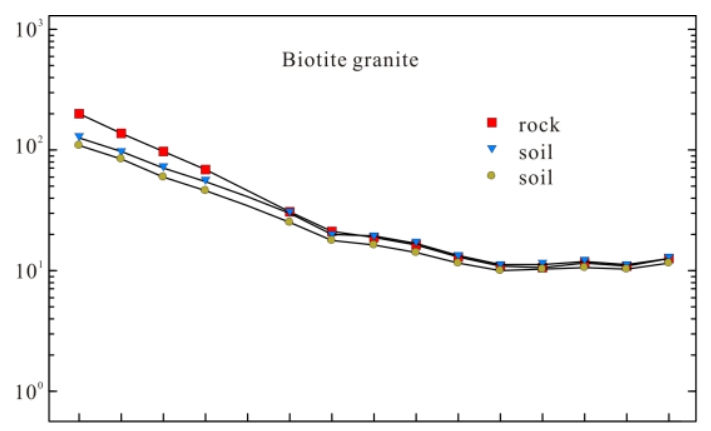

$\mathrm{La} \mathrm{Ce} \mathrm{Pr} \mathrm{Nd} \mathrm{Pm} \mathrm{Sm} \mathrm{Eu} \mathrm{Gd} \mathrm{Tb} \mathrm{Dy} \mathrm{Ho} \mathrm{Er} \mathrm{Tm} \mathrm{Yb} \mathrm{Lu}$

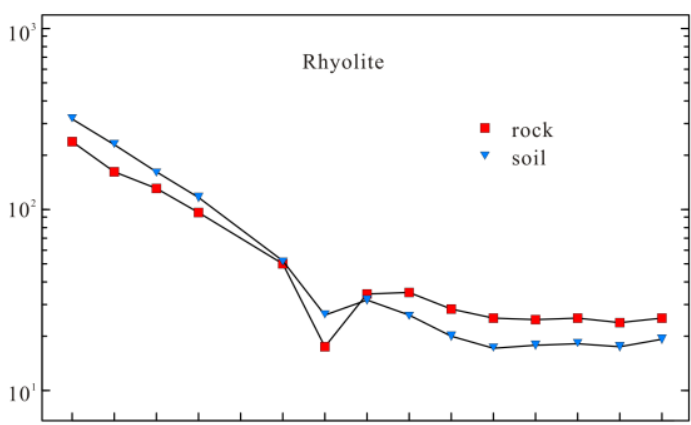

La Ce Pr Nd Pm Sm Eu Gd Tb Dy Ho Er Tm Yb Lu

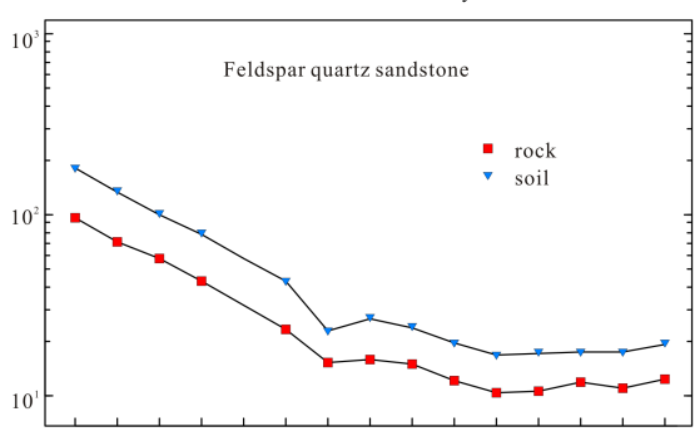

La $\mathrm{Ce}$ Pr Nd Pm Sm Eu Gd Tb Dy Ho Er Tm Yb Lu

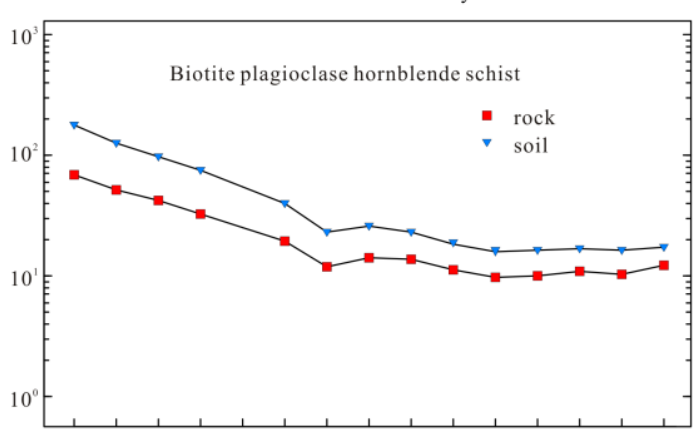

La Ce Pr Nd Pm Sm Eu Gd Tb Dy Ho Er Tm Yb Lu

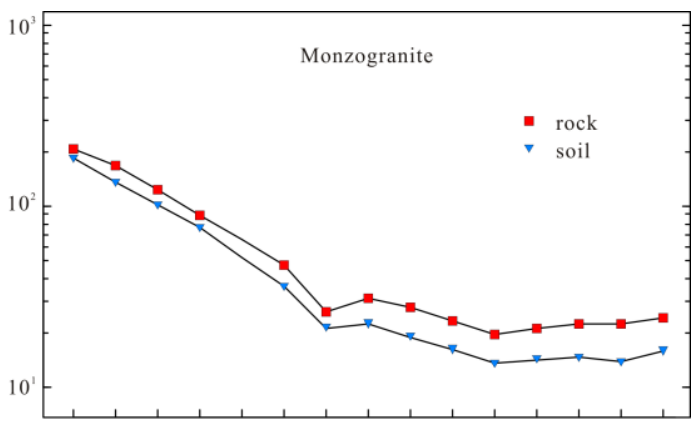

La Ce Pr Nd Pm Sm Eu Gd Tb Dy Ho Er Tm Yb Lu

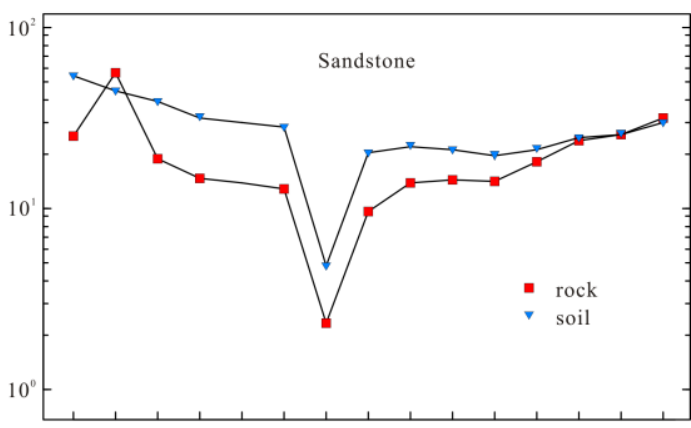

La $\mathrm{Ce}$ Pr Nd Pm Sm Eu Gd Tb Dy Ho Er Tm Yb Lu

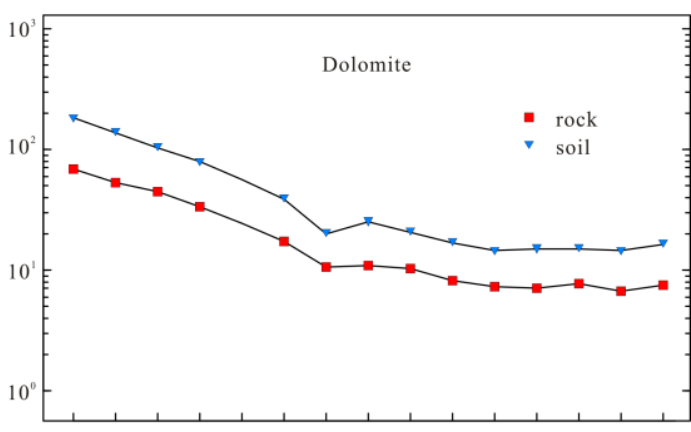

La $\mathrm{Ce} \mathrm{Pr}$ Nd $\mathrm{Pm}$ Sm Fu Gd Tb Dy $\mathrm{Ho}$ - Er Tm Yb Lu

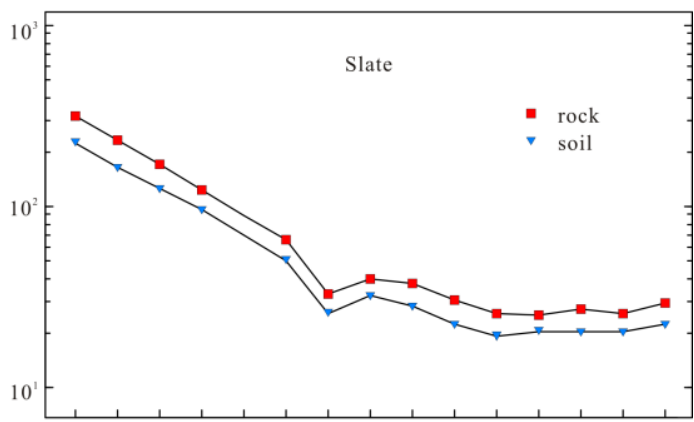

La Ce Pr Nd Pm Sm Eu Gd Tb Dy Ho Er Tm Yb Lu

Fig. 6 Chondrite-normalized (Sun and McDonough, 1989) REE patterns of rocks and in situ weathered soils

\subsection{REE distribution in weathering profile}

One soil profile was collected about $1 \mathrm{~km}$ from the west orebody of the Bayan Obo deposit. Five samples were collected along the weathering profile at about $10 \mathrm{~cm}$ intervals until the bedrock. Each of the samples was sieved into five fractions. The soil type in Bayan Obo is chestnut soil, with a high content of calcium and $\mathrm{pH}$ ranging from 8.2 to 9.1 . 
As shown in Fig. 7, the weathered profile shows a vertical variation in which the REE content decreases from the surface $(0-10 \mathrm{~cm})$ to the middle horizon, but increases near the bedrock. The REE content variation with depth is consistent for all fractions. However, the $\mathrm{CaO}$ content variation with depth is quite different from REE. The $\mathrm{CaO}$ contents in the surface and near the bedrock are very low, but the $\mathrm{CaO}$ content in the middle horizon (10-30 cm) increases tremendously (Fig.8), with a pH of 9.1, indicating the existence of caliche in the middle horizon.

In general, the influencing factors on REE content include parent material, content of clay, carbonate $\left(\mathrm{CO}_{3}\right)$, total organic carbon (TOC) and sesquioxides (Brunsmann and Franz et al., 2001; Ling and Wu et al., 2015; Canovas and Macias et al., 2018; Mihajlovic and Rinklebe, 2018). The chemical/physical soil properties are partly influenced by pedogenic processes which also lead to depletion or enrichment of REEs in parts of the soil profiles since REEs are involved in the processes. In this study, the REEs in the investigated soil profile reveal little relations with TOC, Fe, and Mn oxides. The decrease of REE in the middle horizon is mainly influenced by the existence of a caliche.

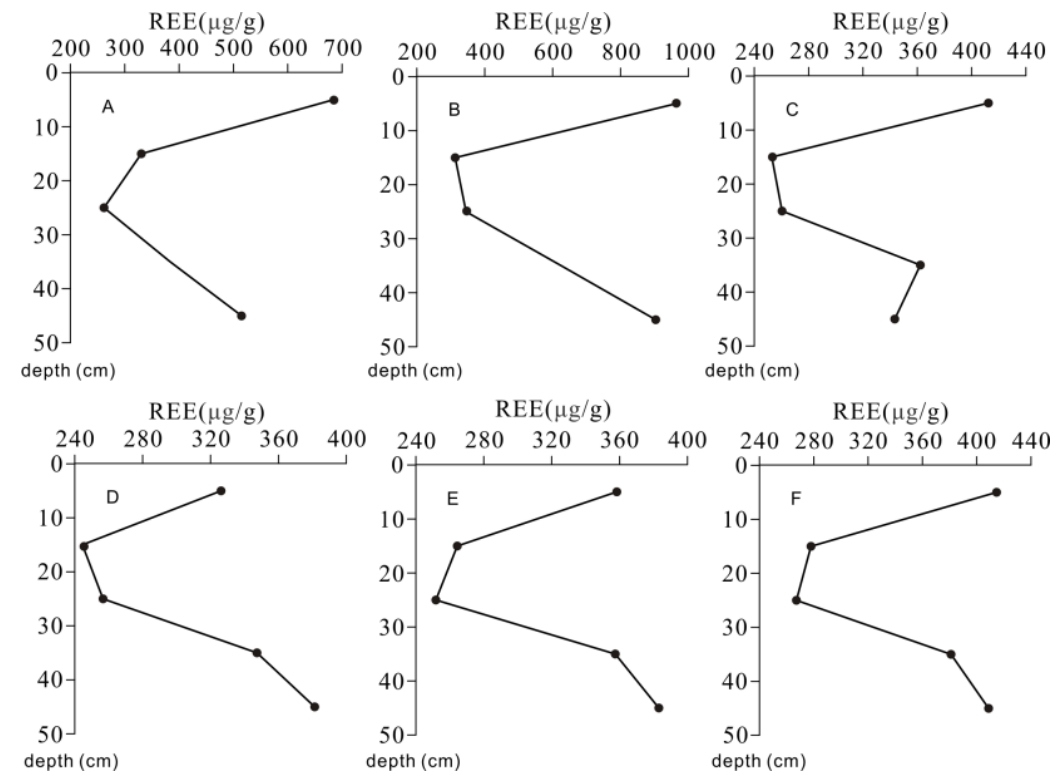

Fig. 7 Depth profile of the REE content for different fractions (A, bulk size; B, 4-20 mesh; C, 20-40 mesh; D, 40-80 mesh; E,80-120 mesh; F, <120 mesh) 

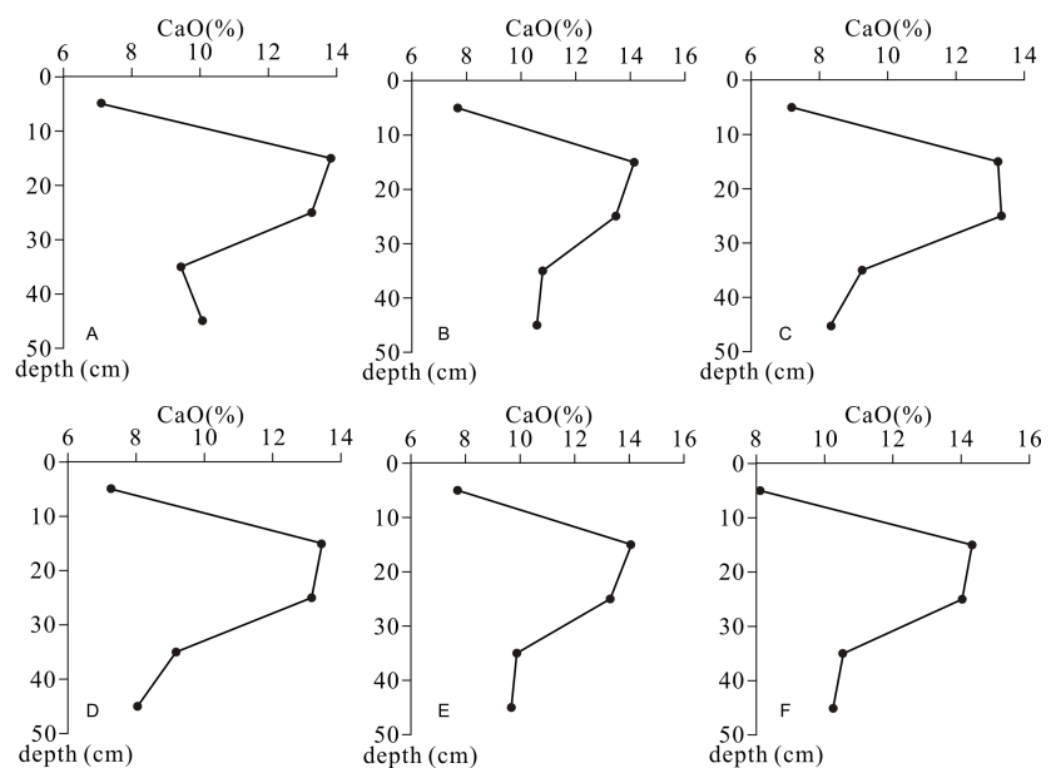

Fig. 8 Depth profile of the $\mathrm{CaO}$ content for different fractions (A, bulk size; $\mathrm{B}, 4-20$ mesh; C, 20-40 mesh; D, 40-80 mesh; E,80-120 mesh; F, <120 mesh)

\subsection{REE dispersion pattern along the stream}

To study the horizontal dispersion pattern of REEs along the stream, research work was carried out along the northwestward streams from the west orebody of the Bayan Obo deposit (Fig.2). The study area is semi-arid grassland region in Inner Mongolia, where the terrain is relatively flat with modest height differences. The streams are seasonal. Chemical elements in the surficial environment are transported mainly by mechanical means. We collected samples every 500-800 $\mathrm{m}$ starting from the west orebody of the Bayan Obo deposit (Fig.2). Each sample was sieved into five fractions: 4-20 mesh, 20-40 mesh, 40-80 mesh, 80-120 mesh, and $<120$ mesh. 

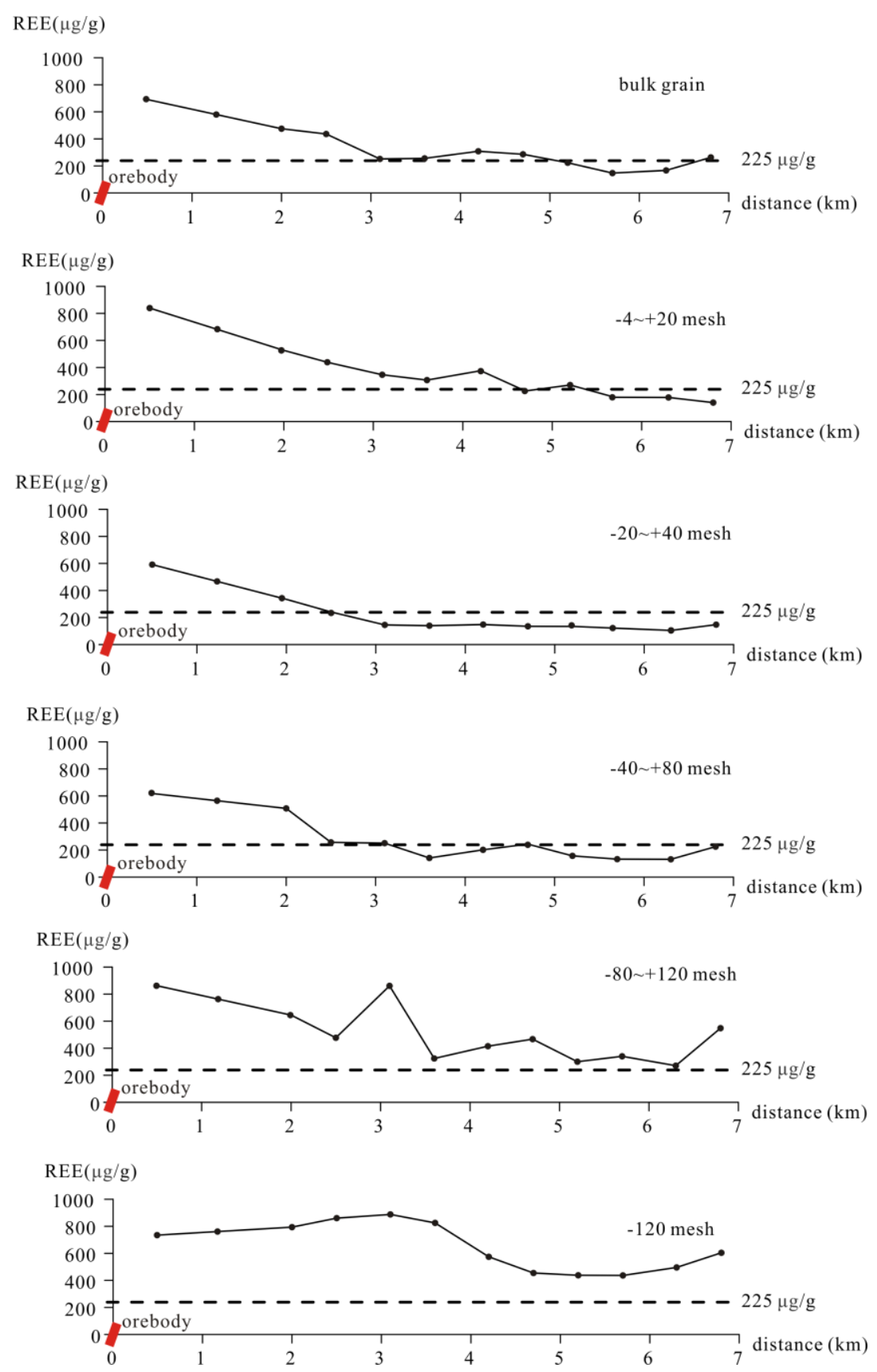

Fig. 9 REE content along the stream for different fractions (Black dotted line represents REE background value of the area, $225 \mu \mathrm{g} / \mathrm{g}$ )

From Fig. 9, we can see that the REE contents in the bulk grain sample decrease rapidly with the migration distance, decreasing to the background value at around 3.0 $\mathrm{km}$ from the orebody. As mentioned above, the 20-40 mesh and 40-80 mesh fractions contain relatively high quartz and feldspar contents, mainly as a result of aeolian sand. With increasing distance from the orebody, the REE content decreases sharply, decreasing to the background value at around $2.5 \mathrm{~km}$ from the orebody. The REE content in the fine fractions $(80-120$ mesh, $<120$ mesh) decreases gradually along the river course, but is still relatively high at $7 \mathrm{~km}$ and has not decreased to the background value. This result indicates that REEs migrate with coarse particles over short distances but can transport over long distances in the form of fine particles. This finding is of great significance to REE geochemical mapping in that REE anomalies cannot be effectively identified at 1: 1,000,000 or global-scale geochemical mapping unless 
fine-grained samples are collected.

Chondrite-normalized (Sun and McDonough, 1989)REE patterns of upstream and downstream samples (Fig. 10) show that the REE content in upstream sediment is higher than that in downstream sediment, and higher LREE/HREE ratios and significant Eu negative anomaly occur in the Chondrite-normalized REE patterns of upstream sediment, indicating distinct provenances of upstream and downstream samples. The REE patterns of different fractions of upstream samples are essentially identical, suggesting that all materials of the upstream sample originate from the same source.

The downstream samples contain a relatively low total REE content for the medium and coarse fractions and a relatively high total REE content for the fine fractions. The fine-grained samples show considerable LREE/HREE ratio and an obvious negative Eu anomaly, while the coarse-grained samples have relatively low LREE/HREE ration and obscure negative Eu anomaly. This signifies different material sources for the downstream coarse-grained samples and fine-grained samples. A comparison with the REE distribution pattern of the upstream samples reveals that the downstream fine-grained samples share the same REE distribution pattern with the upstream samples. This further confirms that the downstream fine-grained materials were transported over long distances from upstream, which has resulted in a high REE content in these materials. The downstream medium- and coarse-grained materials are mainly products of in-situ weathering. Therefore, physical weathering is the main weathering process in this area. REEs in the surficial environment migrate by mechanical means and REEs can migrate with fine-grained particles over long distances $(7 \mathrm{~km}$ or longer). Coarse-grained samples, in contrast, were typically remained in situ.
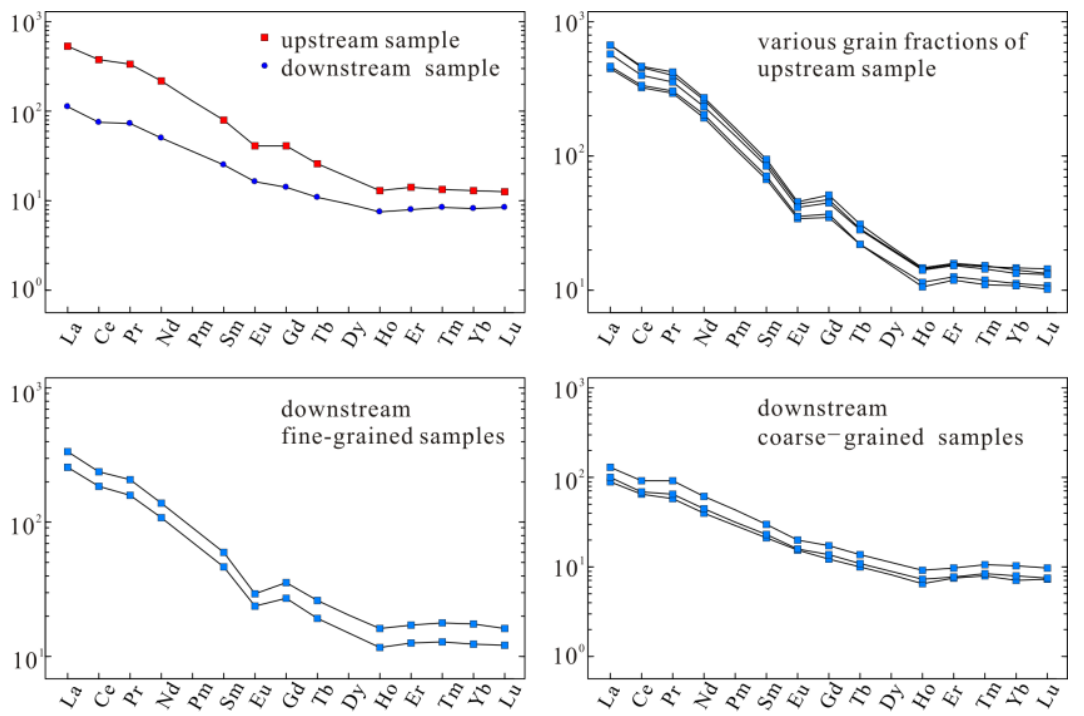

Fig. 10 Chondrite-normalized (Sun and McDonough, 1989) REE patterns of upstream and downstream samples

\section{Conclusions}

In Bayan Obo, slate and acidic rocks contain higher REE contents than quartz, sandstone, or limestone. Within the Bayan Obo group, the REE contents in Bilute Formation slate, Jianshan Formation slate, and Dulahala Formation slate are far higher 
than those in the continental crust or the continental crust of the North China Craton. The REE contents are also far higher than that in ordinary slate. During subsequent stages of magmatism, these rocks might have provided sufficient REE sources to form this giant world-class REE deposit of Bayan Obo.

Although the main orebody of the Bayan Obo deposit has been mined for a long time, the northwestern area of the west orebody has remained basically uncontaminated. The REE content in soil is primarily determined by the parent rock. The chondrite normalized REE patterns of soils are similar to that of the parent rocks, indicating that in semi-arid grasslands region, basically, no fractionation will occur between heavy and light REEs after the parent weathering. Hence, it is possible to determine the sources of the REEs by the REE distribution pattern in sediments.

Across the soil weathering profile, REEs are typically enriched on the surface and deep layers. In the middle horizon, the REE content is usually lower due to the existence of caliche in the middle horizon.

REEs migrate along streams primarily by mechanical means in semi-arid grassland region in Inner Mongolia. REEs can migrate with fine-grained samples over long distances (7 km or longer), whereas coarse-grained samples typically remained in situ. Affected by aeolian sand, the REE content is relatively low in 40-80 mesh fraction.

Our findings provide useful information for preventing REEs contamination and for the geochemical exploration of REEs.

\section{Acknowledgment}

We would like to express sincere appreciation to Prof. Jennifer McKinley from the Queen's University Belfast for the original manuscript and language revision. We also thank the editors and reviewers who have put considerable time and effect into their comments on this paper.

This study is financially supported by the programs of the National Key R\&D Program of Deep-penetrating Geochemistry (2016YFC0600600), International Science Cooperation Program of Mapping Chemical Earth: The Belt and Road Geochemical Mapping Project (121201108000150005) and National Nonprofit Institute Research Grant of CAGS (No. AS2012J01, JYYWF20182401).

\section{References:}

Alonso, E. and A. M. Sherman, et al. (2012). "Evaluating rare earth element availability: a case with revolutionary demand from clean technologies." Environ Sci Technol 46 (6): 3406-14.Dutta, T. and K. 
H. Kim, et al. (2016). "Global demand for rare earth resources and strategies for green mining." Environ Res 150: 182-190.

Gao, S. and R. L. Rudnick, et al. (2004). "Recycling lower continental crust in the North China craton." Nature 432 (7019): 892-7.

Hong-Rui, F. K. Y. F. (2016). "The giant Bayan Obo REE-Nb-Fe deposit, China: Controversy and ore genesis." 地学前缘: 英文版 7 (3): 335-344.

Liu, S. and X. Liu, et al. (2018). "Fenitization in the giant Bayan Obo REE-Nb-Fe deposit: Implication for REE mineralization." Ore Geology Reviews 94: 290-309.

Liu, Y. and M. Ling, et al. (2018). "The formation of the giant Bayan Obo REE-Nb-Fe deposit, North China, Mesoproterozoic carbonatite and overprinted Paleozoic dolomitization." Ore Geology Reviews 92: 73-83.

Mihajlovic, J. and J. Rinklebe (2018). "Rare earth elements in German soils - A review." Chemosphere 205: 514-523.

Pan, Y. and H. Li (2015). "Trace elements in scalp hair from potentially exposed individuals in the vicinity of the Bayan Obo mine in Baotou, China." Environ Toxicol Pharmacol 40 (3): 678-85.

Smith, M. P. and L. S. Campbell, et al. (2015). "A review of the genesis of the world class Bayan Obo $\mathrm{Fe}$ - REE - Nb deposits, Inner Mongolia, China: Multistage processes and outstanding questions." Ore Geology Reviews 64: 459-476.

Sun, J. and X. Zhu, et al. (2014). "Is the Bayan Obo ore deposit a micrite mound? A comparison with the Sailinhudong micrite mound." International Geology Review 56 (14): 1720-1731.

Wang, L. and G. Jiao, et al. (2018). "Environmental Load of Iron Ore Transportation, Bayan Obo Mine, China." IOP Conference Series: Earth and Environmental Science 208: 12004.

Yang, X. and X. Lai, et al. (2017). "Genesis of the Bayan Obo Fe-REE-Nb formation in Inner Mongolia, North China Craton: A perspective review." Precambrian Research 288: 39-71.

Zhong, Y. and M. Zhai, et al. (2015). "Detrital zircon U - Pb dating and whole-rock geochemistry from the clastic rocks in the northern marginal basin of the North China Craton: Constraints on depositional age and provenance of the Bayan Obo Group." Precambrian Research 258: 133-145.

Zhou, B. and Z. Li, et al. (2017). "Global Potential of Rare Earth Resources and Rare Earth Demand from Clean Technologies." Minerals 7 (11): 203.

Zhou, Z. and M. Hu, et al. (2018). "Coupled U - Pb dating and Hf isotopic analysis of detrital zircons from Bayan Obo Group in Inner Mongolia: Constraints on the evolution of the Bayan Obo rift belt." Geological Journal 53 (6): 2649-2664.

Zhu, X. and J. Sun, et al. (2015). "Sm - Nd isotopic constraints on rare-earth mineralization in the Bayan Obo ore deposit, Inner Mongolia, China." Ore Geology Reviews 64: 543-553.

白鸽 (2012). "我对白云鄂博铁铌稀土矿床的研究过程及往见新识." 地质学报 86 (05): 679-682.

段丽丽 (2012). "白云鄂博矿区土壤重金属污染地球化学评价." 山东理工大学学报(自然科学版) 26 (06): 23-28.

高叶青与丁彩琴等 (2017). "稀土元素富集对白云鄂博矿区8种常见藓类植物生长及其解剖结构特 征的影响." 西北植物学报 37 (01): 23-31.

郭伟与付瑞英等 (2013). "内蒙古包头白云鄂博矿区及尾矿区周围土壤稀土污染现状和分布特征." 环境科学 34 (05): 1895-1900.

孔凡吉与张青等 (2004). "内蒙古二连浩特市-东乌珠穆沁旗半干旱荒漠草原区区域化探方法试 验." 地质找矿论丛 19 (4): 261-269.

林晓芳与张晓娥 (2017). "白云鄂博尾矿坝土壤污染及稀土元素毒性研究现状." 世界最新医学信 
息文摘 17 (52): 87-88.

任天祥与赵云等 (1984). "内蒙干旱荒漠区域化探工作方法初步研究." 物探与化探(05): 284-296. 王学锋与许春雪等 (2019). "典型稀土矿区周边土壤中稀土元素含量及赋存形态研究." 岩矿测试 38 (02): 137-146.

王学求 (2013). "勘查地球化学80年来重大事件回顾." 中国地质 40 (1): 322-330.

王学求 (2013). "勘查地球化学近十年进展." 矿物岩石地球化学通报 32 (02): 190-197.

谢学锦 (1992). "中国化探走向2000年." 物探与化探(02): 81-86.

杨晓勇与赖小东等 (2015). "白云鄂博铁-稀土-铌矿床地质特征及其研究中存在的科学问题一一兼 论白云鄂博超大型矿床的成因." 地质学报 89 (12): 2323-2350.

Bai, G. " My research process and new insights into the Baiyun Obo iron-niobium rare earth deposit." Acta Geologica Sinica 86(05):679-682 (in Chinese with English abstract).

Duan. L.L. (2012). " Pollution assessments of heavy metals in soils in the mining area of Bayan Obo " Journal of Shandong University of Technology(Natural Science Edition) 26(06):23-28 (in Chinese with English abstract).

Gao. Y.Q. and Ding. C.Q. et al. (2017). " Impacts of REE's Enrichment on Growth and Anatomy of Eight Common Mosses from Baiyun Obo." Acta Botanica Boreali-Occidentalia Sinica 37(01):23-31 (in Chinese with English abstract).

Guo, W. and Fu. R.Y. et al. (2013). "Distribution Characteristic and Current Situation of Soil Rare Earth Contamination in the Bayan Obo Mining Area and Baotou Tailing Reservoir in Inner Mongolia." Environmental Science 34(05):1895-1900 (in Chinese with English abstract).

Kong, F, J, and Zhang. Q. et al. (2004). "Discussion on Regional Geochemical Exploration Method in the Semi-Arid Erlianhaote-Dongwuzhumuqinqi Area,Inner Mongolia." Contributions to Geology and Mineral Resources Research 19(4):261-269 (in Chinese with English abstract).

Lin. X, F, and Zhang, X.E. et al. (2017). "Research Status of Soil Pollution of Bayan Obo Tailing Dam and Rare Earth Elements Toxicity." World Latest Medicine Information(Electronic Version) 17(52):87-88 (in Chinese with English abstract).

Ren. T.X. and Zhao. Y. et al. (1984). "Preliminary Study on Regional Geochemical Exploration Method in Inner Mongolia Arid Desert." Geophysical and Geochemical Exploration (05):284-296 (in Chinese with English abstract).

Wang. X.F. and Xu. C.X. et al. (2019). " Concentration and Fractionation of Rare Earth Elements in Soils Surrounding Rare Earth Ore Area." $\quad$ Rock and Mineral Analysis 38(02):137-146 (in Chinese with English abstract).

Wang. X.Q. (2013). " Landmark events of exploration geochemistry in the past 80 years " Geology in China 40(1):322-330 (in Chinese with English abstract).

Wang. X.Q. (2013). " A Decade of Exploration Geochemistry. " Bulletin of Mineralogy, Petrology and Geochemistry 32(02):190-197 (in Chinese with English abstract).

Xie. X.J. (1992). " China's Geochemical Exploration Towards 2000 " Geophysical and Geochemical Exploration (02):81-86 (in Chinese with English abstract).

Yang. X.Y. and Lai. X.D. et al. (2015). "Geological Characteristics and Their Scientific Problems of the Bayan Obo Fe-REE-Nb Deposit: Discussion on the Origin of Bayan Obo Super-large Deposit." Acta Geologica Sinica 89(12):2323-2350 (in Chinese with English abstract).

Sun, S. S., McDonough, W. F.,(1989). Chemical and Isotopic Systematics of Oceanic Basalts: Implications for Mantle Composition and Processes. In: Saunders, A. D., Norry, M. J., eds., Magmatism 
in Ocean Basins. Geological Society London, Special Publication, 42: 313-345. 